\title{
Electricity outages and its effect on small and medium scale enterprises (SMEs) in Nigeria
}

\author{
Eyitayo Francis Adanlawo \\ Department of Communication Science \\ University of Zululand, South Africa \\ Makhosazana Vezi-Magigaba \\ Department of Business Management \\ University of Zululand, South Africa
}

\section{Keywords}

SMEs, Economic growth, Electricity outages, Jeremy Bentham Theory

\begin{abstract}
Constant electricity supply enhances smooth running and performances of SMEs. However, electricity outages in Nigeria have been identified as one of the factors hindering SMEs' performance. This study aimed at exploring the impact of electricity outages on the operations and contributions of $S M E s$ to Nigeria economy. Hence, the study evaluated the impacts of electricity supply on the growth of SMEs in Nigeria. It analysed the hindrances that deficient electricity supply could have on the growth and development of SMEs. Survey method was employed to administer structured questionnaires to 110 SMEs operators in three local government areas of Mainland, Shomolu and Agege in Lagos state, Nigeria. Descriptive statistics was utilised to analyse the collected data. A chi square method was used to test the formulated hypothesis. Findings revealed that electricity outages have significant effects on SMEs in Nigeria. The study recommends among other things that, state and local governments should join hands with federal government in generating electricity to ensure stable electricity supply; cost-benefit back-up generating plant is also recommended to keep business operative.
\end{abstract}

\section{Introduction}

Small and medium enterprises (SMEs) are significant to nations' economic growth and development (Eniola and Ektebangm, 2014). According to Adanlawo, Vezi-Magigaba and Owolabi (2021), SMEs role is significant to the development of many societies. Despite SMEs contribution to economic development, they are plagued with many challenges that hinder their optimal contribution to economic growth and development. Adewuyi and Emmanuel (2018); Muhammed et al. (2017) in their studies indicated irregular power supply as one of the major challenges confronted by SMEs in Nigeria. Ogundipe and Apata (2013) aver that SMEs require steady and uninterrupted power supply for production and provision of goods and essential services. According to Doe and Asamoah (2014), stable electricity is the foremost driver for industrial development that will result to economic growth. Scott et al. (2014) asserts that access to a consistent and affordable electricity supply is essential for smooth production of goods and services to meet mankind needs. Conversely, consistent supply of electricity to the SMEs is critical to the sustenance of middle-income status of many developing nations.

However, epileptic electricity supply is common is most developing African nations, and thus hinder substantial contribution to economic development. According to Iwayemi (2018), a total loss of output estimated at US\$470billion (N71 trillion) in terms of gross domestic product (GDP) has been recorded between 1999 and 2015 in Nigerian economy due to power outages. Poor access to electricity supply has been recognized as a deterrent to growth of business activities (Ugwoke et al., 2016; Doe and Asamoah, 2014; Ogundipe and Apata, 2013). Also, World Bank Enterprise Survey in 2014 indicated that 35.5\% of the small and medium scale firms in Nigerians indicated electricity outages as worrisome trouble to business operations (WBES, 2014). Seemingly, Adisa et al. (2014) in their study declare that fluctuations in electricity voltage and power outages affect the quality of goods and services. The result implies that electricity infrastructure is a genuine imperative on SME performance. Hence, this study explored the effect that electricity outages have on the performance of SMEs located in Lagos state, 


\section{Research Question:}

Do electricity outages have significant impact on SMEs performance in Lagos state, Nigeria?

\section{Hypothesis}

The study was guided with this hypothesis:

H1: Electricity outages do not have significant impact on the performance of SMEs operators in Lagos State, Nigeria.

\section{Electricity supply and outages}

Electricity supply is a necessity for basic production of goods and services by small and medium scale operators. Doe and Asamoah (2014) aver that SMEs' access to adequate and affordable supply of electricity is a pivotal determinant for business profitability and growth. Conversely, Duru and Yusuf (2017) in their study concluded that access to electricity contributes to the development of existing rural SMEs to modernized ones. The authors add that constant electricity supply ensures development of new enterprises. Thus, constant electricity is imperative to the operative performance and sustainability of SMEs operations. As indicated by Doe and Asamoah (2014), SMEs owners have a high reliance on electricity as their effective productivity depend on constituent power supply, without which customers' satisfaction cannot be attained.

Doe and Asamoah (2014) submit that stable and easy access to electricity supply is critical to nations' economic growth and development. This implies that electricity consumption is a significant indicator for SMEs growth. Ogundipe and Apata (2013) study found a strong connection between electricity consumption and economic growth. Likewise, Rud (2012) proclaims that electricity supply and its consumption are connected with efficiency and economic development. Akinyele et al. (2016) affirm that regular and affordable supply of electricity has a pivotal implication in business sustainability and economic growth. As constant electricity supply is essential to business growth and development, so, also, the outages and irregular supply of electricity could have adverse effects on small businesses.

Nuredeen et al. (2018) submit that power outages could have affect SMEs expansion and lead to untimely liquidation. Electricity outages could adversely impact the profitability of SMEs (Scott et al., 2014). As opined by Abotsi (2016), electricity outages diminish production efficiency in most developing nations. Over the years, electricity outages have continued to frustrate many business activities in different parts of Nigeria (Adewuyi and Emmanuel, 2018). It is visible that electricity outages have limited expansion of SMEs and discouraged many local and foreign investors. Olatunji (2019) declares that electricity outages have led to migration of many business organisations from Nigeria to different nations. Moyo (2012) concurs that electricity outages affect firms' productivity in Nigerian manufacturing sector. In a nutshell, unstable electricity supply is a serious problem confronting SMEs in Nigeria.

Muhammed et al. (2017) established that electricity supply determines financial performance of the SMEs, especially, manufacturing sector. It is agreed that inadequate electricity supply contrarily influences the efficiency and profit ratio of SMEs (Alhelou et al., 2019; Nkosi and Dikgang, 2018). It is agreed that constant availability of electricity to SMEs has the inclination to impact employment, destitution, profitability and productivity (Nuredeen et al., 2018; Akinyele et al., 2016). This implies that constant electricity supply will alleviate the operators from incurring unnecessary expense on alternative back-up. As posited by Muhammed et al. (2017), economic development and sustainability of SMEs are determined by regular electricity supply for production of goods and services. Therefore, this study as well confirms constant electricity supply as a necessity for SMEs operations and productive capability.

In the realization of the potentials of SMEs to make a meaningful contribution towards nation's economic development, federal government of Nigeria have initiated and adopted several strategies to promote SMEs. Most of the programmes could not make visible contribution in the face of unstable electricity supply. Few of the strategies are discussed below:

Strategies adopted to enhance SMEs' operations by the Nigerian Government

According to Windapo et al. (2020); Sokoto and Abdullahi (2013), numerous strategies have been employed at different times by various successive governments in Nigeria to enhance SMEs. These include: 


\section{Establishment of Small and Medium Enterprises Development Agency of Nigeria (SMEDAN)}

Small and Medium Enterprises Development Agency of Nigeria (SMEDAN) came into existence through an enabling Act 2003. SMEDAN has the responsibilities to fulfill the main task of promoting and encouraging development projects. SMEDAN's major pre-occupation is to SMEs to prepare the beneficiaries for maintainable profit growth. The programme trained SMEs operators on how to efficiently use their finance. Having taken a cursory look into contribution of SMEDAN to SMEs performance, enabling environment still to remain a factor militating optimal performance of newly created millions of SMEs (Windapo et al., 2020).

\section{Central Bank of Nigeria (CBN) propelled Micro, Small and Medium Enterprises Development Fund (CBN-MSME FUND)}

The Central Bank of Nigeria (CBN) propelled the Micro, Small and Medium Enterprises Development Fund (MSMEDF) on August 15, 2013, as a major aspect of its developmental activity and financial advancing system (Ibrahim and Audu, 2020). This was in acknowledgment of the critical commitments of the MSMEs as sub-part of the economy and to bridge financial gap that categorized the sector. The fund recommends 50:50 proportions for on-loaning to SMEs by participating financial institutions (PFIs). Likewise, $2 \%$ of the fund went to economically active people living with disabilities (PLWD), while $10 \%$ was made available for newly started businesses (Ibrahim and Audu, 2020). The expansive goal of the fund is to channel low interest funds of single digit of $9 \%$ to the sub-sector of the MSME in Nigeria through participating financial institutions (PFIs).

A survey carried-out by National MSME in 2015 on the impact and relevance of this fund shows that most applicants could not access the fund based on PFIs recommendation. Above all, the performance of this fund nose-dives on the assumption of office of new government. The discontinuity prevalence of policy in Nigeria has affected this initiative (National MSME Survey, 2015).

\section{The Youth Enterprise with Innovation in Nigeria (YouWiN) Programme (YouWiN)}

The Youth Enterprise with Innovation in Nigeria (YouWiN) Programme was a cooperation of the Ministry of Finance, Ministry of Communication Technology, Ministry of Youth Development and Ministry of Women Affairs and Social Development under the administration of President Goodluck Jonathan. The programme propelled yearly business plan competition (BPC) for ambitious young businessmen in Nigeria (Okpanachi et al., 2016). The programme was intended to empower youthful Nigerians whose age fall between 18-45 years. The youth are to exhibit enterprising aptitudes by beginning their own ventures and providing jobs for others (Obe, 2019). The scheme aimed to generate more job opportunities for the citizenry.

According to Adebayo (2016), YouWiN1, which was the initiative principal version was initiated to prepare pioneering (innovative) young people for employment creation by financing their plans. The subsequent version (YouWiN2) was a Mono-sex form that awarded more than 1200 female young people. The third version (YouWiN3) was Poly-sex; it had a record of awardees of more than 2500 young people. Evaluating the impacts of these programmes on the growth of SMEs as the objective was to promote SMEs in Nigeria; YouWin programme created more than 26,000 jobs at various sectors of the economy (Jonathan, 2013). Though, the programme has been critiqued to have been unable to empower many youths (Adebayo, 2016). Firstly, unemployed youth were not adequately covered in comparison with the number of unemployed youths in the nation. More importantly, infrastructural deficit, especially electricity outages where no doubt undermines the capacity of the programme to ensure its purpose and target.

\section{Theoretical Framework/Relevance}

\section{Jeremy Bentham's Felicific Calculus Theory}

The theory of utilitarianism of felicific and ethical calculi was propounded by Jeremy Bentham. The felicific calculus is a calculation detailed for ascertaining the degree or measure of joy that a particular activity is probably going to cause. According to Baujad (2009), Bentham's calculus is viewed as a single process with different phases. To Bentham, the felicific analytics could decide the ethical status of any thought about act. Numerous factors are to be incorporated in this calculation, which are:

i. Intensity: the robustness the strength of the joy 
ii. Length: what will be the duration of the joy?

iii. Certainty or uncertainty: how possible is the joy occurrence?

iv. Propinquity or remoteness: when will the pleasure occur?

v. Fruitfulness: Probability that the action will be trailed by vibes of a comparative kind.

vi. Virtue: likelihood that it is not trailed by vibes of the contrary kind.

vii. Degree: what number of individuals will be influenced?

For ethical calculus, which is the application of mathematics to calculate issues in morals, Francis Hutcheson committed a section of his 1725-page book "Inquiry into the Original of our ideas and Beauty and Virtue" to an endeavor to present a Mathematical Calculation in subjects of morality (Hutcheson, 1769).

Formulas comprised $\mathrm{M}=\mathrm{B}$ * $\mathrm{A}$; where,

$\mathrm{M}$ : is the moral importance of any agent

$B$ : is the benevolence of the agent

A: is the ability of the agent

\section{Methodology}

The study is quantitative, it employed questionnaire as the instrument for data collection. A Simple random sampling technique was used to select a total of 110 SMEs operators/owners from the list of registered SMEs in Lagos state. Three local government areas of Mainland, Shomolu and Agege in Lagos state were purposely chosen based on nearness to the researcher. To give equal chance of being selected, the list was arranged in ascending order. Thirty-seven (37) SMEs were selected from both Mainland and Shomolu local government areas, leaving thirty-six for Agege local government. Simple random sampling allows an equal chance to every individual to be selected from the population (Acharya et al., 2013). A self- administered questionnaires was administered to these SMEs owners at their business locations and completed questionnaires were collected within three weeks. All the administered questionnaire was retrieved, making the exercise a $100 \%$ success. Consent forms were also given to the participants. Collected data was analysed using descriptive statistics, while chi square method was used to test the formulated hypothesis.

\section{Presentation and Discussion of Findings Age distribution of respondents}

The importance of age in every aspect of life cannot be over-estimated. Because of its significance, this study decided the age structure of the respondents. Data from below table indicates that $(n=25+57)$ which constitutes $74.5 \%$ of the entrepreneurs fall within active working population between age group of 18 and 60 years, while 19\% $(n=19)$ of the respondents fall within dependent group of over 60years.

Table 1. Age distribution of Respondents

\begin{tabular}{|l|l|l|}
\hline Options & No of Respondents & Percentage (\%) \\
\hline $18-30$ years & 25 & $22.7 \%$ \\
\hline 31- 60years & 57 & $51.8 \%$ \\
\hline Over 60years & 21 & $19 \%$ \\
\hline Missing & 7 & $6.3 \%$ \\
\hline Total & 110 & 100 \\
\hline
\end{tabular}

\section{Respondents' literacy level}

Education is a prime factor that can influence invaluable success in SMEs. According to Adanlawo and Vezi-Magigaba (2021), education will influence technical know-how and managerial aptitude of SMEs operators. Table 2 below showcases $47.2 \%(n=52)$ of the respondents as secondary/high school leavers, while $36.3 \%(n=40)$ of the respondent are tertiary institution graduates. The education composition of the respondents is an advantage to SMEs' development and economic growth. 
Table 2. Distribution of level of literacy

\begin{tabular}{|l|l|l|}
\hline Options & No of Responses & Percentage \% \\
\hline Primary School & 9 & $8.1 \%$ \\
\hline Secondary School & 52 & $47.2 \%$ \\
\hline Tertiary Institution & 40 & $36.3 \%$ \\
\hline Missing & 9 & $8.1 \%$ \\
\hline Total & 110 & 100 \\
\hline \multicolumn{2}{|l}{ Source: Field Survey, 2018 }
\end{tabular}

\section{Classification of respondents' SMEs operation}

SMEs activities can be classified into production, semi- production and service. Table 3 indicates that $4.5 \%(n=5)$ of the respondents indulge in table water and beverages production, $8.1 \%(n=9)$ in transport and logistics, while $15.4 \%(\mathrm{n}=17)$ are into printing and publishing services. $3.6 \%(\mathrm{n}=4)$ are into fashion and textile service and semi- production (tying and dying of Adire), marketing and distribution services constitute $41.8 \%(\mathrm{n}=46)$, while $16.3 \%(\mathrm{n}=18)$ of the respondents are into education and training. The remaining $10 \%(\mathrm{n}=11)$ of the respondents did not indicate their businesses. The table portrays that the vast majority of the respondents are into marketing and distribution activities which are corollary to production. Unfortunately, SMEs which are into production have the least respondents in this survey. This is an indication that business owners are moving away from production that require constant electricity supply. This result correlates with Muhammed et al. (2017) and Moyo (2012) findings that electricity outages have more adverse effects on manufacturing SMEs.

Table 3. Distribution of respondents' SMEs activities

\begin{tabular}{|l|l|l|}
\hline Options & No of Respondents & Percentage $\%$ \\
\hline Table water and beverages & 5 & $4.5 \%$ \\
\hline Transport and logistics & 9 & $8.1 \%$ \\
\hline Printing and publishing & 17 & $15.4 \%$ \\
\hline Fashion and textile & 4 & $3.6 \%$ \\
\hline Marketing \& distribution & 46 & $41.8 \%$ \\
\hline Education and training & 18 & $16.3 \%$ \\
\hline Missing & 11 & $10 \%$ \\
\hline Total & 110 & 100 \\
\hline
\end{tabular}

Source: Field Survey, 2018

\section{Most reliable source of power}

As indicated in Table 4, 70.9\% $(\mathrm{n}=78)$ of the respondents rely on generator to run their enterprises, while $22.7 \%(n=25)$ depends on electricity supply. The remaining $6.3 \%(n=7)$ abstained from the question. Generator (alternative power generator) usage ought to be an alternative source of power, but it has become the main source of power. Generator usage is at higher cost and not affordable to most entrepreneurs in developing nations like Nigeria. This finding validates Scott et al. (2014); Duru and Yusuf (2017) findings that electricity insecurity and alternate power usage adversely impacts the profitability of SMEs in many developing nations.

Table 4. Most Reliable Source of Power of Respondents

\begin{tabular}{|l|l|l|}
\hline Options & No of respondents & Percentage (\%) \\
\hline Electricity & 25 & $22.7 \%$ \\
\hline Generator & 78 & 70.9 \\
\hline Missing & 7 & $6.3 \%$ \\
\hline Total & 110 & $100 \%$ \\
\hline
\end{tabular}

Source: Field Survey, 2018 


\section{Preferred Source of Power}

Most entrepreneurs if not all will prefer electricity which is cheaper, safer and accessible for their businesses. Electricity as a source of power is unreliable in Nigeria. The quality of Nigeria's electricity supply ranks 141 out of 148 countries in the World Economic Forums Global Competitiveness Report (2013-2014). As portrays in table 5, 72.7\% $(n=80)$ of the respondents prefer electricity for their business which is hardly available and $21.4 \%(\mathrm{n}=24)$ of the respondents believe in using generator for their enterprises. The remaining $5.4 \%(n=6)$ of the respondents abstained from answering the question. The result clearly portrays people's preference for electricity usage. This validates Akinyele et al. (2016) finding that electricity is cheaper and most affordable to small businesses.

Table 5. Preferred source of power by respondents

\begin{tabular}{|l|l|l|}
\hline Options & No of Responses & Percentage (\%) \\
\hline Electricity & 80 & $72.7 \%$ \\
\hline Generator & 24 & $21.8 \%$ \\
\hline Missing & 6 & $5.4 \%$ \\
\hline Total & 110 & $100 \%$ \\
\hline
\end{tabular}

Source: Field Survey, 2018

\section{Impact of Electricity on Small Businesses}

Evidence from table 6 depicts that $73.6 \%(n=81)$ of the respondents indicated that electricity has significant impact on their business. Another $20 \%(n=22)$ designated that electricity has little effect on their business, while $4.5 \%(n=5)$ expressed that there is no impact of electricity on their business. The remaining $1.8 \%(\mathrm{n}=2)$ did not answer the question. This survey verifies the findings of Olatunji (2019); Adewuyi and Emmanuel (2018); Muhammed et al. (2017) that electricity outages/insecurity affects the activities of SMEs in developing countries.

Table 6. Impact of Electricity on the Business of Respondents

\begin{tabular}{|l|l|l|}
\hline Options & No of respondents & Percentage (\%) \\
\hline high impact & 81 & $73.6 \%$ \\
\hline Mild impact & 22 & $20 \%$ \\
\hline No impact & 5 & $4.5 \%$ \\
\hline Missing & 2 & $1.8 \%$ \\
\hline Total & 110 & $100 \%$ \\
\hline
\end{tabular}

Source: Field Survey, 2018

\section{Test of Hypotheses}

$\mathrm{H}_{0}$ : Electricity does not affect the performance of SMEs operators in Lagos State.

Chi-square Tests

\begin{tabular}{|l|l|l|l|l|l|}
\hline & $(\mathrm{O})$ & Expected & $(\mathrm{O}-\mathrm{E})$ & $(\mathrm{O}-\mathrm{E})^{2}$ & $\left(\begin{array}{l}(\mathrm{O}-\mathrm{E})^{2} \\
(\mathrm{E})\end{array}\right.$ \\
\hline Large Extent & 81 & 27.5 & 53.5 & 2852.25 & 104.08 \\
\hline Mild Extent & 22 & 27.5 & 5.5 & 30.25 & 1.1 \\
\hline Poor Extent & 5 & 27.5 & -22.5 & 506.25 & 18.41 \\
\hline Missing & 2 & 27.5 & -25.5 & 650.25 & 23.65 \\
\hline Total & 110 & & & & 147.24 \\
\hline
\end{tabular}

Interpretation:

Calculated chi square of 147.24 is greater than table chi square of 12.59 . The results indicate that $\mathrm{X}^{2}$ calculated is greater than $\mathrm{X}^{2}$ tabulated, therefore, the null hypothesis that electricity outages do not affect the performance of SMEs operators in Lagos state is rejected. The alternative hypothesis that electricity outages significantly affect the performance of SMEs in Lagos state is accepted. The result corroborates Olatunji (2019); Adewuyi and Emmanuel (2018); Duru and Yusuf (2017); Iwayemi (2017); Akinyele et al. (2016) and Doe and Asamoah (2014) findings which specify that electricity outages/irregular supply of electricity significantly affects SMEs' performances and responsible for closure of many manufacturing businesses. 


\section{Conclusion}

With the reviewed literature, theory underpinning the study and survey carried out, this study concludes that electricity outages adversely affect the growth and contribution of SMEs to nation's building. Evidence portrays that several programmes have been initiated to promote SMEs, but most of them were not effective due to irregular supply of electricity/electricity outages (Olatunji, 2019); Muhammed et al., 2017). If we placed the appraisal of recent government policies (SMEDAN, YouWin and CBN MSME Fund) against the ethical calculus of Jeremy Bentham theory in which $M=B$ * $A$. Where, $\mathrm{M}$ is the moral importance of any agent; $\mathrm{B}$ is the benevolence of the agent; and $\mathrm{A}$ is the ability of the agent. The impact of these initiatives is short-termed and insignificant as irregular electricity supply hinders production of goods and provision of essential services by the SMEs. This study concludes that the chance of any initiated programme to succeed in the face of electricity insecurity is slim. As a result, the moral importance of these initiatives with the confronting constraint of electricity insecurity to its good success is highly questionable. Therefore, this study affirms that electricity is essential to sustainability of small businesses.

\section{Recommendations}

The issue of electricity/power supply cannot be left as a sole duty of Federal government. State governments together with local governments in Nigeria should emulate Lagos state government that generate electricity through the Independent Power Project (IPP) to generate and ensure stable supply of electricity to SMEs in order to enhance national economy.

Seemingly, alternative means of electricity generation should be explored by both the federal and state governments so as to create more jobs opportunities.

SME operators should procure a cost-benefit back-up generating plant that will puts their operation costs at minimal rate and avert the risk of untimely liquidation of SMEs.

Regulatory bodies in the energy sector that will design strategies or measures to enhance electricity generation, distribution and costing are recommended to support SMEs in the production of goods and services.

\section{Limitations and direction for future research}

This study was conducted in Lagos, Nigeria, the result might not be generally applicable to all developing nations of Africa. Future research could build on this study by extending the focus to other Africa countries. Also, the effect of electricity outages on production and selling price of goods should be looked-into.

\section{References}

Abotsi, A. (2016). Power Outages and Production Efficiency of Firms in Africa. International of Energy Economics Policy, 6(1), 98-104.

Acharya, A., Prakash, A., Saxena, P. \& Nigam, A. (2013). Sampling: Why and How of it? Indian Journal of Medical Specialities, 4(2), 330-333.

Adanlawo, E. \&Vezi-Magigaba, M. (2021). Informal Financing and the Performance of Small and Medium-Scale Enterprises (SMEs). Psychology and Education journal, 58(4), 3307-3315.

Adanlawo, E. Vezi-Magigaba, M. \& Owolabi, C. (2021). Small and Medium Scale Enterprises in Nigeria: The Effect on Economy and People's Welfare. African Journal of Development Studies, 11(2).

Adewuyi, A. \& Emmanuel, Z. (2018). Electricity Outages and Firm Performance across the Six Geo-Political Zones in Nigeria: The Role of Corruption. MPRA Paper No. 92089. Online at https://mpra.ub.uni-muenchen.de/92089/

Adebayo, P. (2016). Impact of government entrepreneurial programmes on youths SMEs participation in Nigeria. Journal of Business and African Economy, 2(2), 32-45.

Adisa, T., Abdulraheem, I. \& \& Mordi. C. (2014). The Characteristics and Challenges of Small Businesses in Africa: an Exploratory Study of Nigerian Small Business Owners. Economic Insights - Trends and Challenges, III (LXVI), 1-14.

Akinyele, S., Akinyele, F. \& Ajagunna, O. (2016). Infrastructural Development as Predictor to Small \& Medium Enterprises Performance in Nigeria. Kuwait Chapter of Arabian Journal of Business and Management Review, 6(3), 4053.

Alhelou, H., Hamedani-Golshan, E., Njenda, T. \& Siano, P. (2019). A survey on power system blackout and cascading events: Research motivations and challenges. Energies, 12(4), 682.

Baujad, A. (2009). A return to Bentham's felicific calculus: From moral welfarism to technical nonwelfarism. The European Journal of the History of Economic Thought. Online: 
http:/ / www.informaworld.com/smpp/title content=t713698194

Doe, A. \& Asamoah, F. (2014). The Effect of Electric Power Fluctuations on the Profitability and Competitiveness of SMEs: A Study of SMEs within the Accra Business District of Ghana. Journal of competitiveness, 6(3), 32-48.

Duru, I. \& Yusuf, A. (2017). Effect of Electricity Services on Microenterprise: Evidence from Ganaja Village, Kogi State, Nigeria. Asian Research Journal of Arts \& Social Sciences, 4(4), 1-11.

Eniola, A. \& Ektebang, H. (2014). SME firm's performance in Nigeria: Competitive advantage and its impact. International Journal of Research Studies in Management, 3(2), 75-86.

Goodluck Jonathan (2013). Opening speech on the occasion of the $3^{\text {rd }}$ edition of the youth's enterprise with innovation in Nigeria programme, $25^{\text {th }}$ November. Available: http:/ / www.statehouse.gov.ng

Hutcheson, F. (1769). An essay on the nature and conduct of the passions and affections with illustrations upon the moral sense. Robert \& Andrew foulis, 1769.

Ibrahim, S. \& Audu, B. (2020). Youth development policies in Nigeria: Promises, problems and possibilities. KennethDike Journal of African Studies, 1(1).

Iwayemi, A. (2018). Reforming the Nigerian Electric Power Industry: The Challenge to Economic Theory. A Seminar Paper Presented at the Department of Economics, University of Ibadan, Nigeria.

Moyo, B. (2012). Do Power Cuts Affect Productivity? A Case Study of Nigerian Manufacturing Firms, International Business E Economics Research Journal, 11 (10), 23-32.

Muhammed, A., Abdulraheem, I. \& Yusuf, I. (2017). Impact of electricity service quality on the performance of manufacturing SMEs in Nigeria. Journal of Business and Social Review in Energy Economies, 3(1), 1-10.

Nkosi, N. P. \& Dikgang, J. (2018). Pricing electricity blackouts among South African households. Journal of Commodity Markets, 11, 37-47.

Nuredeen, Y., Nafiu, A. \& Jibo, A. (2018). An Investigation of Electricity Power Fluctuations and Performance of Small and Medium Enterprises in Dekina, Kogi State. Journal of Energy Research and Reviews, 1(3), 1-10.

Ogumdipe, A. \& Apata, A. (2013). Electricity Consumption and Economic Growth in Nigeria. Journal of Business Management and Applied Economics, 11(4), 72-88.

Obe, A. (2019). Aspirations and realities in Africa: IV. Nigeria's emerging two-party system. Journal of Democracy, 30(3), 109-123.

Okpanachi, O., Okorie, N. \& Adewale, A. (2016). The YouWiN Entrepreneurship Programme and National Development in Nigeria. International Journal of Economic Development Research and Investment, 7(1), 8-15.

Olatunji, O. (2019). Electricity insecurity and the performance of small-scale businesses in Akoko area of Ondo state, Nigeria. International Journal of Business and Social Science, 10(7), 158-167.

Rud, P. (2012). Electricity Provision and Industrial development: Evidence from India, Journal of Development Economics, 97(2), 352-367.

Scott. A., Darko, E., Lemma, A. \& Rud, J. (2014). How does electricity insecurity affect businesses in low- and middleincome countries? Overseas Development Institute Report; 2014.

Sokoto, A. \& Abdullahi, Y. (2013). Strengthening Small and Medium Enterprises (SMEs) as a Strategy for Poverty Reduction in Northwestern Nigeria. American Journal of Humanities and Social Sciences, 1(3), $189-201$. doi:10.11634/232907811301338

Ugwoke, T., Dike, C. \& Elekwa, P. (2016). Electricity Consumption and Industrial Production in Nigeria. Journal of Policy and Development Studies, 10(2), 87-98.

WBES (2014). World Bank Enterprise Survey: Understanding the Questionnaire. Washington, DC. http:/ / www.enterprisesurveys.org

Windapo, A., Olugboyega, O. \& Odediran, S. (2020). Impacts of procurement strategies on construction SMEs' growth. Journal of Financial Management of Property and Construction, 25(3), 423-446. 